\title{
KAREL HANSA: THE CZECHOSLOVAK TRAVELLER IN SYRIA AND LEBANON IN 1922 AND HIS WORK FOR THE BENEFIT OF ARMENIAN GENOCIDE SURVIVORS ${ }^{1}$
}

\author{
Jiř́i Cukr, Marek Jandák
}

In 1922, the Czechoslovak traveller Karel Hansa visited the French Mandate for Syria and Lebanon, where he became acquainted with the lamentable living conditions and pitiful experiences of the survivors of the Armenian Genocide. He was deeply impressed by the work of Western humanitarian organizations, especially the American Near East Relief. This experience led Hansa to decide to write, lecture and try to organise humanitarian aid for Armenian orphans in Czechoslovakia, although his humanitarian efforts had only limited success.

Key words: Karel Hansa, Armenian Genocide, survivors, humanitarianism, Czechoslovakia, Syria, Lebanon.

\section{Introduction}

In interwar Czechoslovakia, Karel Hansa was the only person who systematically dealt with the subject of the Armenian Genocide. Of significant historical value are his testimonies on the humanitarian situation of the survivors in Syria and Lebanon in 1922, where Hansa documents predominantly the transports of Armenian children from the territories occupied by Turkish nationalists. After his return to Czechoslovakia, Hansa attempted to organise humanitarian aid for Armenian orphans in Czechoslovakia. This transfer of the social practice of modern humanitarian work, as Hansa observed it in the Middle East, to Czechoslovakia did not go without the necessary adaptation to the different local environment. We follow the method with which Hansa tried to inform and mobilise the Czechoslovak public and the ways in which he tried to establish cooperation with Czechoslovak and foreign humanitarian organizations.

Karel Hansa achieved some success in the interwar period as a writer and lecturer, but he was never amongst the prominent figures of the public life in Czechoslovakia. By the second half of the 20th century he was already a forgotten persona. ${ }^{2}$ This began to change

1 The article was received on 20.08.2020 and was accepted for publication on 03.10.2020.

This article was created with support of The Centre for the Transdisciplinary Research of Violence, Trauma and Justice at Charles University (UNCE/HUM/009). Translated by Terézia Klasová. For the purpose of this article, we have studied documents at the following institutions: National Archives of the Czech Republic, Prague (Národní archiv České republiky, NA); Prague City Archives (Archiv hlavního města Prahy, AMHP); the Research Library of South Bohemia (Jihočeská vědecká knihovna, JVK); State District Archives České Budějovice (Státní okresní archiv České Budějovice, SOkA ČB); State District Archives Písek (Státní okresní archiv Písek, SOkA Písek); State Regional Archives Třeboň (Státní oblastní archiv v Třeboni, SOA Třeboň) and State Regional Archives Prague (Státní oblastní archiv v Praze, SOA Prague).

2 For example, his name is absent in most of the historical and contemporary biographical dictionaries. An ex- 
over the last 15 years in connection with the increased interest of the Czech public in the topic of the Armenian Genocide, and also thanks to the activities of the Armenian community in the Czech Republic, which has grown significantly in numbers since the 1990s.

Current research on the life and work of Karel Hansa has its roots around 2006, when Hansa's book Horrors of the East was published in a reprint. Members of the Prague Armenian community, editor-in-chief of Orer (days) Hakob Asatryan and artist Tigran Abramjan, who received support from the Armenian community in Cyprus, ${ }^{3}$ were behind the publication. As part of the then-unsuccessful initiative to recognize the Armenian Genocide ${ }^{4} \mathrm{Czech}$ Senator Jaromír Štětina organised an international conference "The Armenian Genocide," attended by Vahakn N. Dadrian and Tessa Hofmann among the others. The conference took place in the Hall of the Czech Senate on April 4, 2006, and Hansa's work was presented there by Anna Sochová. ${ }^{5}$ In recent years, several short texts ${ }^{6}$ and in 2018 also a professional seminar at the Faculty of Arts, Charles University in Prague, ${ }^{7}$ was devoted to Hansa. In 2020 the city of České Budějovice published Hansa's manuscript dealing with his visit to France in late 1920s. ${ }^{8}$ The Theresienstadt Centre for Genocide Studies plans to start awarding the Karel Hansa Prize in 2021 on the occasion of the commemoration of the International Day of Remembrance and Dignity of the Victims of the Crime of Genocide. ${ }^{9}$

The aim of this article is to connect with and improve the result of current research, and to contribute to international research on the history of the Armenian Genocide and humanitarian work. In this text, we would also like to move beyond the simplistic hagiographical narratives, towards a more complex and at the same time ambivalent interpretation of Hansa's life.

\section{Early Life}

At the end of the 19th century, Vienna was a multicultural metropolis of global importance, where people of all nationalities from the Austro-Hungarian Empire lived. The Czechs were the largest national minority in Vienna around 1900, as many individuals with their entire families came here for a better living or to fulfil their work duties. ${ }^{10}$ It was employment

ception here is the recent Biografický slovnik českých zemí, vol. 22 (Prague: Historický ústav AV ČR, 2019),193194.

3 Karel Hansa, Hrůzy východu (Beroun: Josef Šefl, 1923). The book was reprinted in 2006 in Prague with an additional foreword by Hakob Asatryan.

4 Senator Jaromír Štětina did not succeed in his attempt in 2006, but the Czech Republic recognized the Armenian Genocide in 2017, when the initiative was taken by Deputy Robin Böhmisch. Marek Jandák, Arménská genocida: př́činy, průběh a osobni svědectví 1915-1922 (Prague: Epocha, 2018), 359-365.

5 Jaromír Štětina et al., Mezinárodni konference: Arménská genocida (Prague, 2006), 41-46; Anna Sochová, "Karel Hansa: Očitý svědek následků arménské genocidy," Parrésia 12 (2018): 333-340.

6 Haig Utidjian, The Art of the Armenian Book through the Ages (Červený Kostelec: Pavel Mervart, 2016), 210213; Jiří Cukr, "K dobrodružnému životu Karla Hansy (1890-1967)," Výběr: Časopis pro historii a vlastivědu jižních Čech 53, no.1 (2016): 55-57; Jandák, Arménská genocida, 483-511.

7 Andran Abramjan, Hakob Asatryan, Jiří Cukr, Marek Jandák and Anna Sochová spoke at the event.

8 Karel Hansa, Poznatky a zážitky z Francie = Connaissances et expériences de France (České Budějovice:

České Budějovice 2020). The book is in Czech with a parallel French translation.

9 We received this information from director of the centre, Šimon Krbec, on 30 October 2020.

10 Jana Koudelková, Češi ve Vidni = Tschechen in Wien (Brno: Jihomoravský kraj, 2013). 
in the postal services that brought Karel Hansa Sr. (1858-1918) and his newlywed bride Jarmila (1869-1943) to Vienna shortly after the wedding. Both came from working families. Karel's ancestors were millers, Jarmila's ancestors made their living as bakers.

Their eldest son, named after his father, was born to the newlyweds on November 25, 1890. He was baptized as Karel František Václav Hansa a week later, in the Catholic parish church of St. Jan Nepomucký on Praterstrasse, in the second city district (Leopoldstadt). ${ }^{11}$ Members of the Czech community gathered in this district of Vienna, and the aforementioned church dedicated to the Czech patron was available to them.

The Hansas' stay in Vienna lasted at most three years; their daughter Maria (18911973) was also born there. Their father was soon transferred to a new job, and in 1892 he relocated to České Budějovice (Budweis), which at the time was a growing and prosperous centre with a population of 39,000 (1900), mostly ethnic Czech and Germans. ${ }^{12} \mathrm{He}$ returned to the immediate vicinity of his place of origin, having been born in a neighbouring village where his relatives still owned a farm and operated a mill. At first, Hansa Sr. worked as a postal clerk; later he advanced his career and social status, becoming a postal inspector and then chief postal inspector. ${ }^{13}$ His wife did not have any formal employment; she took care of the children and the household. The Hansa family settled in a small house in an intensively developing suburb, where other siblings of the traveller-to-be Karel - Josefina (1893-1971), Václav (1895-1952) and Jaromír (1902-1956) were born. ${ }^{14}$

In České Budějovice, the young Karel started attending primary school in 1896. There were several schools of all levels in the city; some were single-sex schools, only a minimum of schools was mixed. The schools were also divided into German and Czech schools. ${ }^{15}$ Karel Hansa was not among the best students throughout his studies and he also had received lower grades for behaviour. For example, in the spring of 1902, that means at the age of eleven, Hansa received 3 (two bands reduced grade) in behaviour, since he repeatedly smoked on the street and he did not restrain from this behaviour even after being repeatedly reprimanded. ${ }^{16}$

He did not even finish the middle school in České Budějovice and in the following years he often changed schools and residences. ${ }^{17}$ Changes of schools and residences, at the time uncommonly frequent, lead towards an unstable environment, in which Karel grew up. This experience could have influenced his character traits and his choice of a volatile traveller's life. After forestry training in the Libnič district on the Hluboká estate (1906-1907), ${ }^{18}$ Hansa finally graduated from the renowned Czech forestry school in Písek. ${ }^{19}$

11 Pfarre St. Johann Nepomuk, Wien, Taufbuch 1890-1892.

12 Population of the town: 17000 (1869), 24000 (1880), 28500 (1890) 39000 (1900), and 44500 (1910). Encyklopedie Českých Budějovic (České Budějovice: Nebe, 1998), 327.

13 Budweiser Kreisblatt, 15 May 1904, 4-5.

14 SOkA ČB, collection Archiv města České Budějovice, book 3011, fol. 64.

15 Encyklopedie Českých Budějovic, 490-491.

16 SOkA ČB, collection I. národní škola České Budějovice, book 25; collection I. střední škola Jírovcova ulice České Budějovice, book 15.

17 SOkA Písek, collection Měšt’anská škola chlapecká Písek, book 5 and 6. SOkA ČB, collection Základní škola Lišov, book 10 .

18 SOA Třeboň, collection Schwarzenbergská ústřední kancelář Hluboká nad Vltavou, sign. 12 F 4a. 19 SOkA Písek, collection Vyšší lesnická a revírnická škola Písek, book 49. 


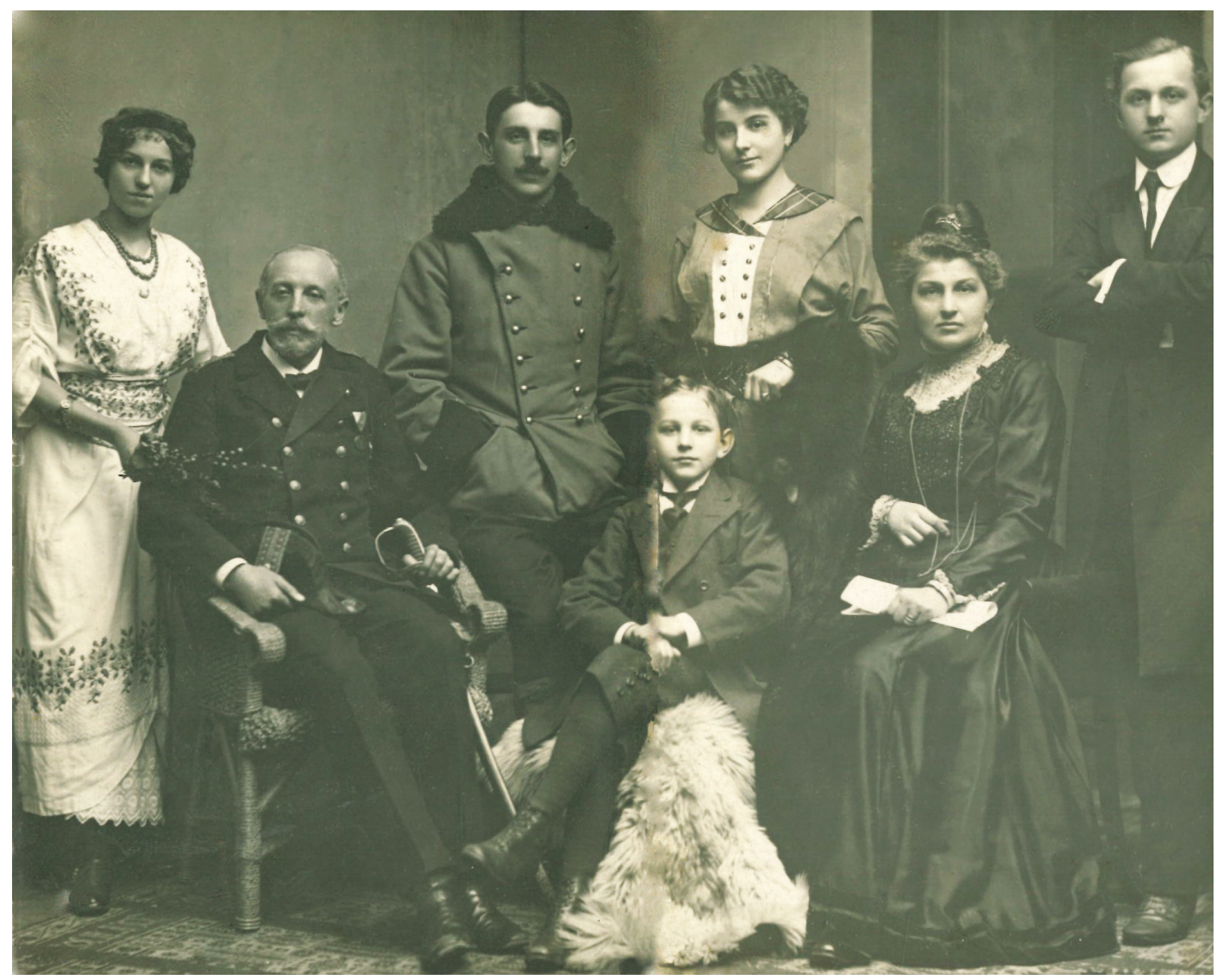

Figure 1. The Hansa family, around 1910. Sitting from left to right Karel Sr., Jaromír and Josefína Sr., standing Josefína, Karel, Marie and Václav.

Source: Family collection

In the spring of 1910, Karel was participating in military service in the Hulan Cavalry Regiment. Later, Hansa moved to the former Ottoman province of Bosnia and Herzegovina, which Austria-Hungary had occupied since 1878 and annexed in 1908. As one of the more than 7,000 Czechs who had come here for work until then, Hansa viewed Bosnia and Herzegovina as part of the Orient, with which Austria-Hungary had a colonial relationship. ${ }^{20}$ Hansa first worked as a forester in the town of Han Pijesak, then as a wood warehouse manager in nearby Sarajevo, and finally in Teslić with a Bosnian joint-stock company for wood processing. ${ }^{21}$

During WWI, he fought as sergeant in the 12th Hulan Regiment for the Habsburg Empire. In the autumn of 1915, he was severely wounded in his right forearm on the Russian battlefield around the Dniester River. Later, during his visit to Budapest, Hansa remembered

$\overline{20}$ Zdeněk Uherek, Češi v Bosně a Hercegovině (Prague: Etnologický ústav AV ČR, 2011), 39-40; Clemens Ruthner, "Habsburg's Only Colony? Bosnia-Herzegovina and Austria-Hungary, 1878-1918," Seeu Review 13 , no. 1 (2018): 2-14.

21 SOA Prague, collection Velkostatek Liteň, box 91, inv. no. 93; Hansa, Z potulek Orientem (České Budějovice: self-published), 281. 
the doctors ("the butchers" as he called them) telling him there in 1915 that amputation of the hand is necessary; otherwise he will die from blood poisoning. He added: "I didn't give in, I disagreed." Hansa managed to preserve his arm and his life, but in 1922 the trauma from his injury still lingered: "I unwittingly raised my hand and saw the scars caused by the insidious dum-dum missile." ${ }^{22}$ He received a silver medal of the first class for his bravery, but he had to face the consequences of the injury for the rest of his life, since as a consequence he classified as "three-quarters handicapped." 23

After the end of the war, Hansa found a new job in the independent Czechoslovak Republic as a woodsman on the Liten estate southwest of Prague. ${ }^{24}$ However, after half a year, he moved directly to Prague, where he became the secretary of the forest workers' union. In the years 1920-1922 he was also mentioned as editor of forestry magazines.

\section{Experience with Armenian Genocide Survivors and Near East Relief}

Czechoslovakia was founded at the end of WWI on the territory of the former Austro-Hungarian monarchy. The basic concept in its state-building was the Wilsonian right to self-determination, which in this case concerned the Czechs and Slovaks, as they formed at least in theory a Czechoslovak political nation. However, Czechoslovakia was a de facto multinational state of Czechs, Germans, Slovaks, Hungarians, Rusyns, Poles and Jews, which was associated with the former Austria-Hungary not only by its liberal democratic establishment, but also by complex and often conflicting relations between its individual ethnic groups and large economic differences between the west and east of the state.

At the beginning of the 20th century there was a Czech expatriate community in the Ottoman Empire. Contact between the Bohemian lands and the Ottoman Empire was provided primarily by travellers, scientists and various people carrying out economic activity, and thus not missionaries or colonial officials. ${ }^{25}$ During WWI, some Czech citizens of the Habsburg monarchy fought in the Ottoman Empire as its allies. The famous Czech Orientalist Alois Musil ${ }^{26}$ had a prominent place among them; however, no testimony by any Czech soldier about the Armenian Genocide is known. On the other hand, unique eyewitness testimony of the violence between Armenians and Azerbaijanis in Baku in March and September 1918 does come from the Czech engineer Jan Kolár. ${ }^{27}$

\footnotetext{
22 Hansa, Z potulek Orientem, 16.

23 Verlustliste, no. 286, (Wien 1915), 17; JVK, sign. P 5.392, Karel Hansa, Poznatky a zážitky z Francie (Prague: manuscript, 1949-1950), appendix "Poznávejte svět!," 10. Henceforth this source will be cited as "Manuscript (1949-1950).” NA, collection Policejní ředitelství II, Všeobecná spisovna 1941-1950, box 2853, sign. H-671/8, Hansa's letter to directorate, January 1925 (henceforth this source will be cited as "Police Directorate").

24 SOA Prague, collection Velkostatek Liteň, box 91, inv. no. 93.

25 Miloš Mendel, Bronislav Ostřanský, Tomáš Rataj, Islám v srdci Evropy (Prague: Academia 2007); Adéla Jůnová Macková et al. (eds.), Českoslovenští vědci v Orientu, vol. I (Prague: Scriptorium, 2012), 37-49; Petr Pabian, "Islam in Czech Travel Literature of the Nineteenth Century," in: "We" and "the Others," ed. Lud'a Klusáková, (Prague: Karolinum, 2004); Josef Kořenský, Asie: kulturní obrázky z asijského jihu a západu (Prague: Storch 192?), 204-206.

26 Oldřich Klobas, Alois Musil zvaný Músa ar Rueili (Brno: CERM, 2003); Karel Jaroš, Z turecké armády do britského zajetí (Prague: Paseka, 1995).

27 Jan Kolár̆, Na vlnách revoluce v zemi věčných ohňủ (Prague: Československá grafická unie, 1936), 24-35.
} 
Czech and Slovak post-communist historiography has so far hardly reflected post-colonial theory in the interpretation of the history of Czechoslovakia. ${ }^{28}$ For the purposes of this article, we will conceptualize the situation here as "colonialism without colonies." 29 This means that, although Czechoslovakia did not have control over any overseas colony and belonged to the European semi-periphery, it was linked to the global economy and to the discourses associated with colonialism and imperialism. For example, during the peace negotiations after WWI the idea (never to be realised) of acquiring Togo, former German colony in West Africa, became popular in Czechoslovakia for a short time. ${ }^{30}$

In the interwar period, Hansa cited "orientalist traveller and writer" as his profession. While working in Bosnia and Herzegovina, and during a visit to Syria and Lebanon in 1922, he encountered the colonial relationships of the Habsburg Monarchy and France, with respective the former territories of the Ottoman Empire. His relatively strong experience with colonialism was unusual in Czechoslovakia. Hansa based his texts on the ideas of the paternalistic duties of the "cultural west," perceived black skin as an object of exoticization and stereotyped occidental and oriental women; ${ }^{31}$ however during his stay in Syria and Lebanon he was not directly associated with the French colonial apparatus.

28 Filip Herza, "Colonial Exceptionalism: Post-colonial Scholarship and Race in Czech and Slovak Historiography," in Slovenský národopis 68, no. 2 (2020): 175-187; Pavel Barša, "The Zero Degree of Decolonisation," Artalk Revue 4 (2020), at https://artalk.cz/wp-content/uploads/2020/01/AR-4-EN-162045.pdf, accessed 20.09.2020. See also Michael Borovička, Velké dějiny zemí Koruny české: Cestovatelství (Prague: Paseka, 2010), 545-551; Macková et al. (eds.), Českoslovenští vědci v Orientu, vol. I, 22-25.

29 Patricia Purtschert, Francesca Falk, Barbara Lüthi, "Switzerland and 'Colonialism without Colonies,"” Interventions 18, no. 2 (2015): 286-302. See also: Matthias Bjørnlund, "Karen Jeppe, Aage Meyer Benedictsen, and the Ottoman Armenians: National Survival in Imperial and Colonial Settings," Haigazian Armenological Review 28 (2008): 11-17.

30 Pavel Kosatík, České sněni [Czech Dreams] (Prague: Torst, 2010), 192-206.

31 Hansa, Z potulek Orientem, 59, 89-92, 175-176, 183-187, 269-284. 


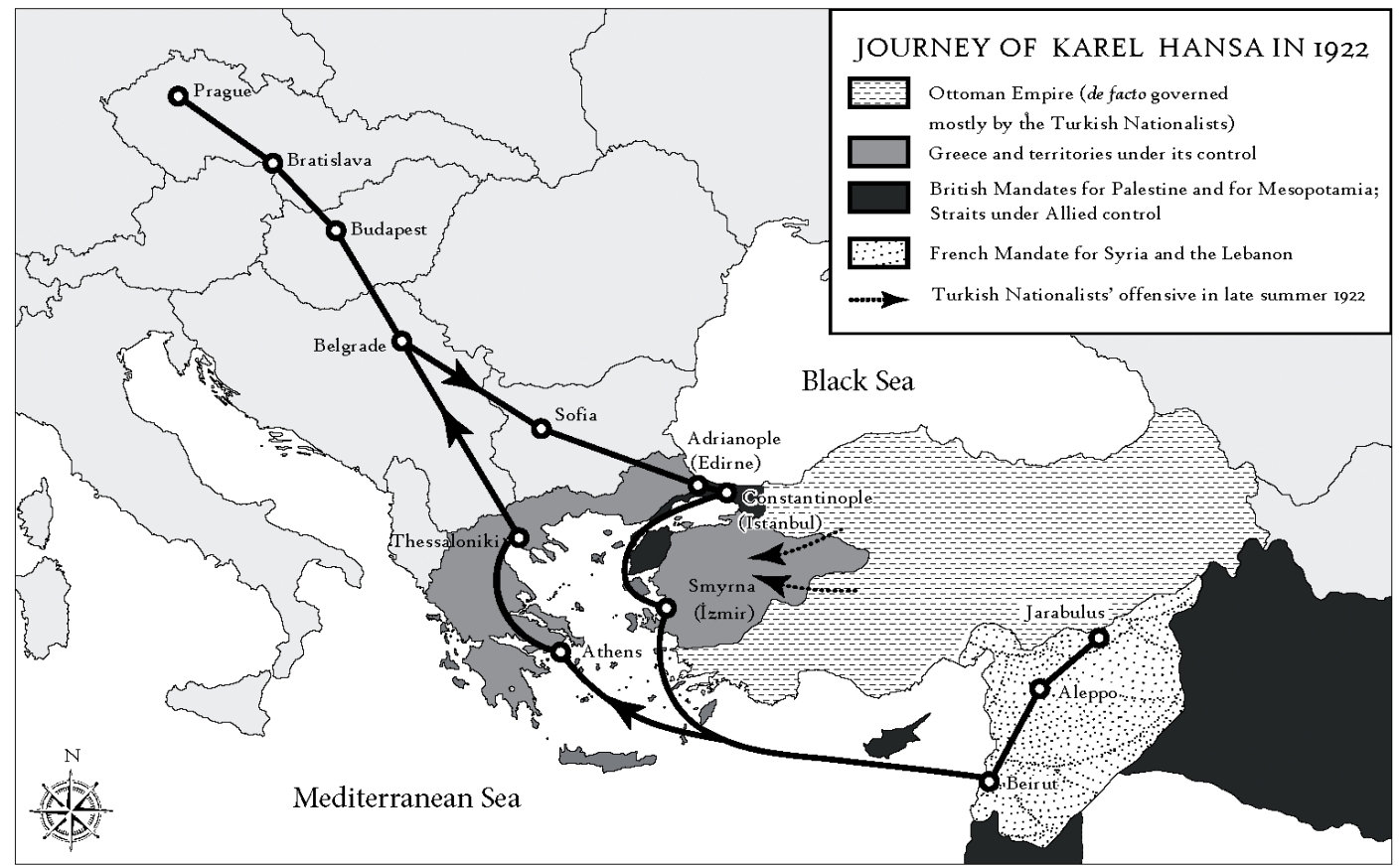

Figure 2. Map of Karel Hansa’s Journey, by Martin Ď́sek and Marek Jandák.

Source: Jandák, Arménská genocida, 488

Hansa's decision to leave Czechoslovakia in the early summer of 1922 was an escape from the problems of his love life and an attempt to forget in a new, unknown environment. ${ }^{32}$ At first he was briefly employed in Yugoslavia, where, thanks to his knowledge of Serbian and German, he found a position in the administration of an aristocratic residence in the town of Futog in Bačka.

Subsequently, equipped with diaries and a camera and dressed as a woodsman, he set out on a train journey through Adrianople (Edirne) to Constantinople. In mid-July 1922, Hansa decided to continue his journey on the steamboat Hiperochy via Smyrna (İzmir) to Syria and Lebanon. During his journey, he relied on the help of expatriate communities in Constantinople and Aleppo, and Czechoslovak diplomatic missions in Belgrade, Constantinople, Smyrna and Athens. ${ }^{33}$ Hansa's now lost diary entries became the basis for some chapters in his book The Horrors of the East (1923) and for the travelogue From Wanderings through the Orient (1925). His writings are full of short stories from his travels and descriptions of everyday life.

Southeast Europe and the parts of the Middle East where Hansa travelled were severely marked by WWI and a number of subsequent conflicts. Not only soldiers and state borders were on the move, but also refugees and genocide survivors. At the time of Hansa's visit, Adrianople and Smyrna were still controlled by the Greek army, and the troops of the Entente were still occupying Constantinople. The Czech traveller witnessed the culmination

32 Ibid., 5, 181. Hansa, Hrůzy východu, 132. Police Directorate, documents relating to Hansa's passport.

33 Hansa, Z potulek Orientem, 70, 73, 75 (Czechoslovak communities in Constantinople), 123-129 (Aleppo), 
of the exodus of the Greeks from Anatolia in the Middle East and from Greece after the crushing defeat of the Greek armies in the war with the Turkish nationalists (1919-1922). ${ }^{34}$ In addition, the presence of Russian emigrants in Hansa's texts illustrates the global extent of the post-war refugee crisis. ${ }^{35}$

Lebanon was struck with famine during WWI. ${ }^{36}$ North-eastern Syria became a major destination for the deportation of the Armenian population in 1915, and the second phase of the Armenian Genocide took place here a year later. ${ }^{37}$ The territory of the French Mandate for Syria and the Lebanon has therefore become a key place in the process of the shaping of modern humanitarianism.

Attempts to rebuild Armenian communities led mainly by the American Near East Relief (NER) and the League of Nations, failed due to a series of defeats of the French colonial forces in Cilicia by Turkish nationalists in 1920 and 1921. Turkish nationalists subsequently expelled genocide survivors from Cilicia and eastern provinces of the Ottoman Empire. ${ }^{38}$ Approximately 200,000 genocide survivors were concentrated in Syria and Lebanon in provisional conditions in 1922, in the hope that in the future they would be permanently resettled in Anatolia or in Soviet Armenia. It was only after 1926 that the French authorities began their permanent establishment directly on the territory of the mandate. ${ }^{39}$

Hansa arrived in Aleppo, Syria, at the turn of July and August 1922. The humanitarian consequences of the Genocide and the ongoing exodus of the Armenians were clearly visible in the city itself. This is how the Czech traveller captured the contrast between the French headquarters, where the military band was just giving a concert, and the plight of Armenian children in the streets:

In the magnificent headquarters building, where the power and strength of a glittering golden sword gleaming in the glare of innumerable lights intertwined, the partying society completely forgot about the slender child creatures wrapped in tatters of their dirty clothes, huddled together in the alcoves of the palace, one warming up another and lying down to sleep at night - like those street dogs! ${ }^{40}$

24, 279 (Czechoslovak diplomatic missions in Belgrade), 83 (Constantinople), 98-101 (Smyrna) and 98 (Athens).

34 Ibid., 99, 251-254.

35 Ibid., 53-54, 264-265. See also Philipp Ther, The Outsiders: Refugees in Europe Since 1492 (Princeton: Princeton University Press, 2019), 54-69.

36 Keith D. Watenpaugh, Bread from Stones: The Middle East and the Making of Modern Humanitarianism (Oakland: University of California Press, 2015), 45-56.

37 Raymond Kévorkian, The Armenian Genocide: A Complete History (New York: I. B. Tauris, 2011), 625-696, 743-762; Hilmar Kaiser, "The Armenians in Lebanon during the Armenian Genocide," in Armenians of Lebanon, ed. Aida Boudjikanian (Beirut: Haigazian University, 2009), 31-58.

38 Levon Marashlian, "Finishing the Genocide: Cleansing Turkey of Armenian Survivors, 1920-1923," in Remembrance and Denial, ed. Richard G. Hovannisian (Detroit: Wayne State University Press, 1999), 113-145.

39 Vahé Tachjian, "L'établissement définitif des réfugiés arméniens au Liban dans les années 1920 et 1930," in Armenianas of Lebanon, 59-66.

40 Hansa, Z potulek Orientem, 197. 


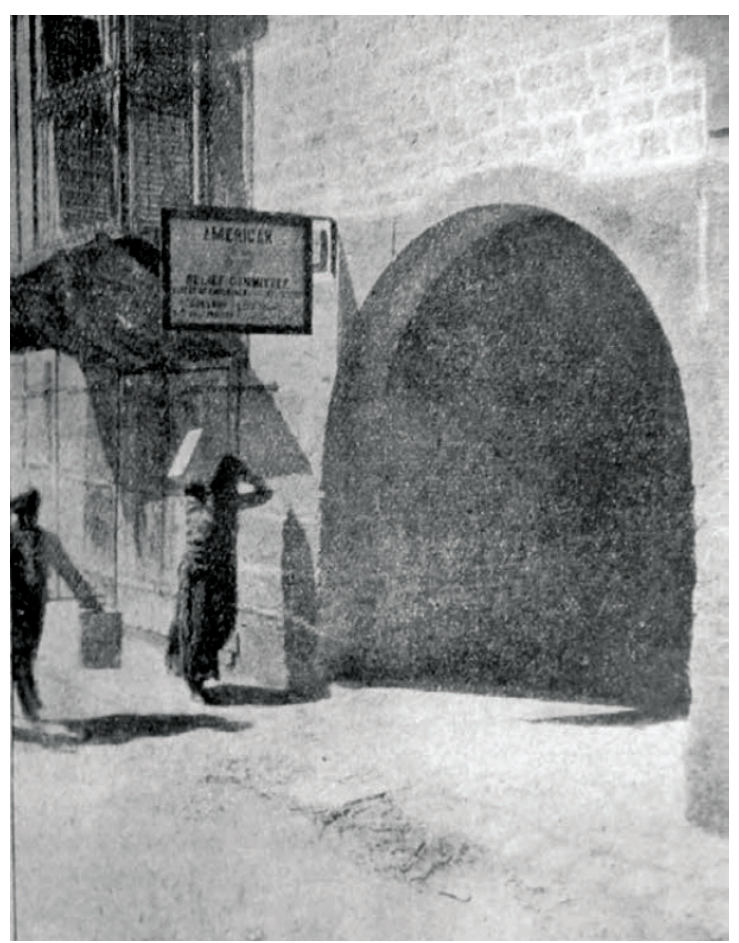

Figure 3. A sign in the English, Armenian and Arabic languages, marking the building of American Near East Relief in Aleppo.

Source: Hansa, Hrüzy východu

At a time when Hansa had difficulty finding affordable housing due to a lack of funds, he met Vahan Melikian, a NER official. Hansa allegedly impressed him with his willingness to "help one old woman in her misfortune," so he arranged accommodation directly in the organization's house after coming to an agreement with the director of the NER in Aleppo Hermann Kreider (1898-1967). ${ }^{41}$ Subsequently, Hansa participated in the humanitarian activities of the NER, although he was not an employee but a guest.

NER was founded in New York in 1915, in response to reports of the ongoing extermination of the Armenian population. From the beginning, the organization distributed aid in cooperation with missionaries and American consuls in the region. After WWI, the NER expanded significantly by sending hundreds of humanitarian workers to the Middle East and through extensive fundraising in the United States, which generated an average of 12 million U.S. dollars a year between 1919 and 1923. ${ }^{42}$ The NER, in cooperation with other smaller and mostly European partners, was part of an international network of non-governmental humanitarian organizations whose goal was to provide systematic and long-term

41 Ibid., 150-152, 180-189. Hansa, Hrüzy východu, 114. Amerikan Bord Heyeti (American Board), Istanbul, "Personnel records for Herman H. Kreider," American Research Institute in Turkey, Istanbul Centre Library, online in Digital Library for International Research Archive, item \#13203, at http://www.dlir.org/archive/items/ show/13203, accessed 22.09.2020.

42 James L. Barton, Story of Near East Relief (1915-1930) (New York: Macmillan Company, 1930), 410. 
assistance to Armenians, Greeks and other people in need in the Middle East and Greece. ${ }^{43}$

In 1922, approximately 70,000 Armenian and Greek children, whom NER decided to evacuate from their orphanages in the Ottoman Empire, passed through Aleppo. ${ }^{44}$ As an example of Hansa's activity with NER, we can mention the fact of his accompanying one of these children's transports.

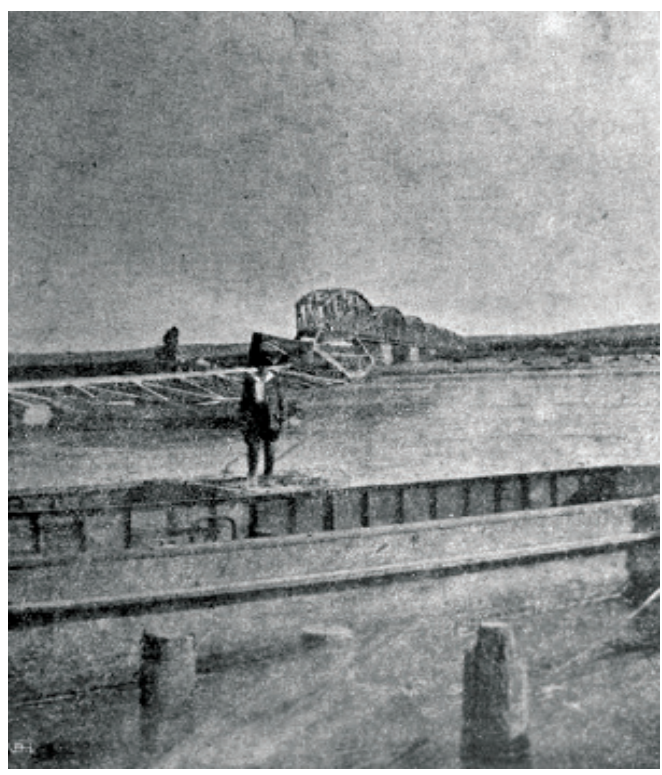

Figure 4. Railroad bridge across the Euphrates River near the Jarabulus station of Bagdad railway; it was partially destroyed by the explosives during the World War. The man in the photograph is Hansa himself.

Source: Hansa, Hrůzy východu

Jarabulus, a town at the border with Turkey, lies on the Euphrates River, which separated the French mandate in the south and the area controlled by the Turkish nationalists in the north. Hansa arrived here after a wild Ford car ride with three Turks employed by the NER, as they could easily cross the border into eastern Anatolia. One of them, the eccentric Enwer [sic], became Hansa's guide and interpreter into German during his stay in Aleppo. ${ }^{45}$ A NER station was set up in Jarabulus in a war-torn building without doors and windows. A group of NER workers, led by the Armenians Karabed [sic] and Said, was waiting for the orphans in order to provide food and lodging for the children. The much-anticipated transport of children travelled from the city of Harpoot through Urfa to Jarabulus. There,

43 Watenpaugh, Bread from Stones, 91-156; Hans M. Jaatun, "From Religious Relief to Development Aid: The Near East Relief and the Emergence of International Humanitarianism, 1915-1930," Global Histories 5, no. 1 (2019): 50-63; Vahram L. Shemmassian, "The League of Nations and the Reclamation of Armenian Genocide Survivors," in Looking Backward, Moving Forward, ed. Richard G. Hovannisian (New Brunswick and London: Transaction Publishers, 2003), 81-112; Nefissa Naguib, Inger M. Okkenhaug (eds.), Interpreting Welfare and Relief in the Middle East (Leiden and Boston: Brill, 2008).

44 Hansa, Hrůzy východu, 112; Hansa, Z potulek Orientem, 211-212.

45 Hansa, Z potulek Orientem, 153-165, 192-195, 201-206. 
they were supposed to cross the river and wait for the train to Aleppo. The children had to undertake a dangerous journey with the help of hired animals tormented by dust, insects and the heat of the sun. In addition, the railway bridge in Jarabulus had been destroyed during WWI, and train traffic to the north was interrupted; the children thus had to use a temporary pontoon bridge.

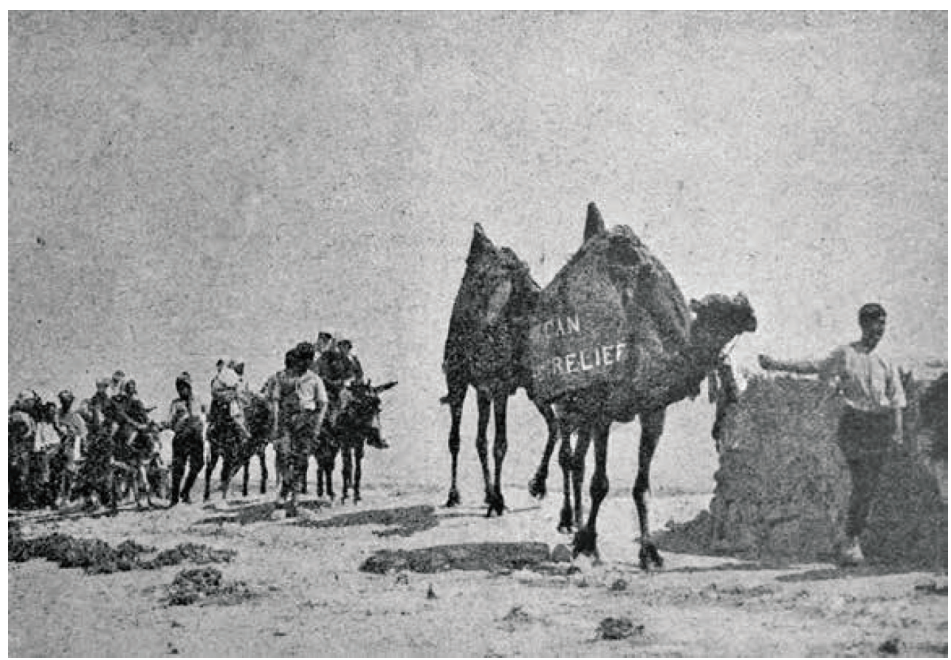

Figure 5. A caravan transporting the orphans across dry desert in northern Syria. Source: Hansa, Hrůzy východu

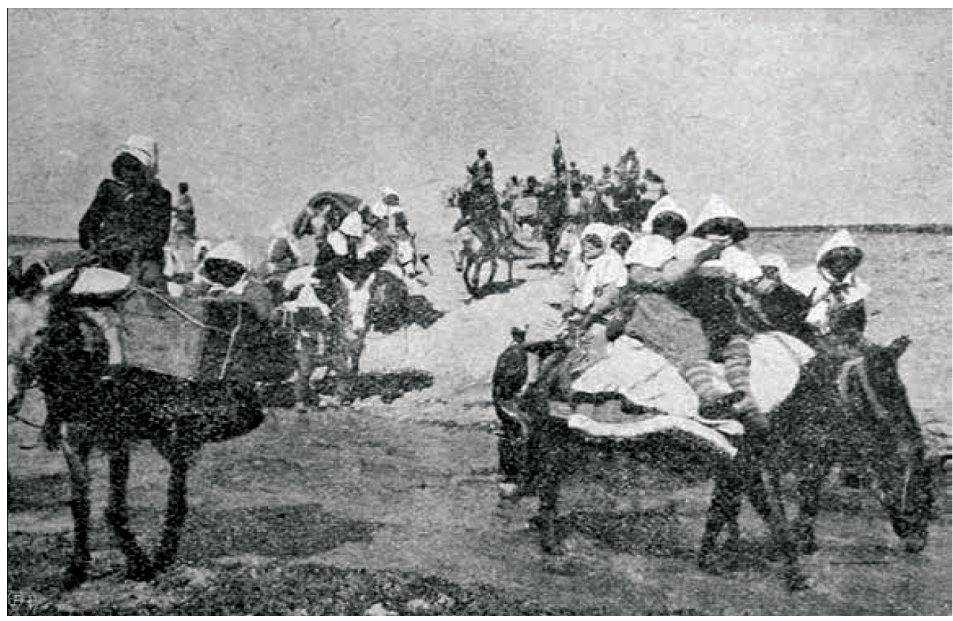

Figure 6. Orphans from Malatia (the children are equipped with hoods against heatstroke). Source: Hansa, Hrůzy východu

Hansa photographed the orphan transports and the refugee camps in Aleppo and Beirut, and later published them in his book Horrors of the East. His sketches from the life of humanitarian workers and orphans capture a number of fleeting moments. For example, we 
can cite a short story about a group of children waiting for cattle wagons to arrive at the Jarabulus station, which shows orphans not only as suffering victims, but also as people actively living their childhood:

I vividly remember one of the boys, approximately 9 years old, who, with the serious face of the diplomat of the flock by which he was surrounded, tried to prove that those who travel in the first carriages, will reach the destination of the journey $[. .$.$] much earlier than their companions in the carriages in the back. With$ his opinion, he caused a revolution among the children. Everyone wanted to get to the front, just behind the machine. [...] For a long time, Said had to make it clear to everyone that their cars would be placed last [...] and that they would all arrive in Aleppo in a heap and at the same time. ${ }^{46}$

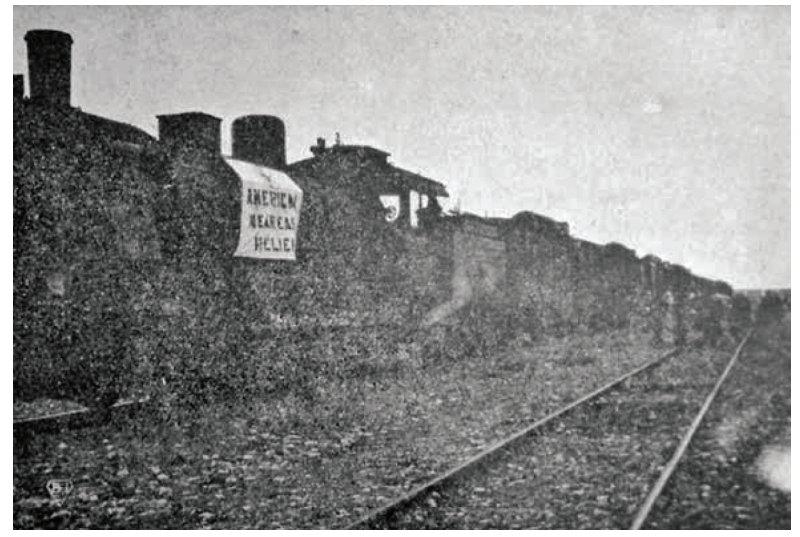

Figure 7. A special train arranged by the American Near East Relief committee at Jarabulus station prepared to take several thousands of children to Aleppo.

Source: Hansa, Hrůzy východu

At the stations in Aleppo and then in Beirut, the transports were awaited by Armenian women, who hoped to find their children there. The arrival of children thus became a place of receiving bad news as well as for family reunification. This is how Hansa captured the meeting of mother and daughter in Beirut:

Only one of the women was fortunate. She found her daughter, an approximately eight-year-old girl, who came from Malatia. There she had left little Sophia in the protection of a prominent Greek family, when she herself had to leave the city with the other Armenian inhabitants and was deported. When the Americans began rescue work for the remnants of the Armenian people of Asia Minor, Sophia was accepted into the care of the committee. The mother recognized her daughter by the sign on the child's neck. With cries of unspeakable joy, she hugged her child, sprinkling her cheeks with a stream of tears. ${ }^{47}$

46 Ibid., 177. See also Donald E. Miller, Lorna T. Miller, Survivors: An Oral History of the Armenian Genocide (Los Angeles: University of California Press, 1993), 118-136; Nazan Maksudyan, Ottoman Children and Youth during World War I (Syracuse: Syracuse University Press, 2019), 105-136.

47 Hansa, Z potulek Orientem, 210-211; Hansa, Hrìzy východu, 111, 113. 
Modern humanitarianism embodied in the work of Hermann Kreider and his colleagues in Aleppo allowed Hansa to reformulate his relationship with refugees and survivors of the genocide he had previously perceived only as a passive observer. Hansa decided to involve Czechoslovakia in international structures to help Armenian orphans. He therefore began collecting material for his book in the refugee camps of Aleppo and Beirut and started to prepare for his return to his homeland. Hansa obtained information about the fates of the survivors with the help of interpreters or directly from German-speaking people. ${ }^{48} \mathrm{He}$ usually did not name his sources unless the individual was in a position of authority, and characterised them according to gender, occupation, age and place of origin.

I personally know one [student] from Zeitun, whose 32-member family was also deported and who were partly murdered during the deportation, partly died of suffering and various diseases. He alone remained alive and was severely wounded; he saved himself by hiding in a pile of corpses after the massacre and fleeing at night. ${ }^{49}$

In addition to including individual stories of survivors, Hansa tried to characterise the problems that the inhabitants of refugee camps had to face:

During my stay in Beirut in November and December last year, during the winter rains and freezing winds, and with very cold and wet nights, visiting local camps almost daily I saw terrible misery, illness and suffering beyond description. Streams of water, rolling incessantly from the clouds, spewed water into every corner of the flimsy tents and huts, where on the soaked and sludge-stained property, often on the bare ground, shivering mothers huddled in the cold, protecting the crying children with their flimsy clothes. The daily influx of water made the camp a real mudflat. There were no spades or shovels, to allow the ditches of water drains to be deepened or built anew. A wild, freezing north wind that had been blowing incessantly for weeks ruthlessly tore the soaked and rotten remnants of blankets and sacks from the tents, which threatened to break free of their pegs in the soaked soil at any moment. For weeks, the weather was terrible and staying in the camps was real suffering. [...] Everyone is coming out of the soaked tents - they are shaking from the cold and poorly dressed. Most are barefoot; emaciated baby legs are shivering with cold and are red as a crayfish. Children are crying - they are hungry. And mothers, with a tear in their eyes, helpless, running through the camp, searching for food for their children or for fuel on which the neediest could cook. There are no hotplates or pebbles, so these poor women have to help themselves with empty kerosene cans, in which they cook breakfast and lunch on a piece of charcoal - but also often dinner also. There is no milk, eggs or fat, so a simple rice soup is the only usual dish. ${ }^{50}$

48 Hansa, Hrůzy východu, 95.

49 Ibid., 99, see also 100, 105.

50 Ibid., 104. 
Elsewhere, Hansa writes about the lack of healthcare and the conditions in which sick children lived in the camps:

It is terrible to see sick little children, often wrapped in dirty rags or in wet strips of sacks, as I have seen during my various visits to camps and tents during the weeks of the autumn rains. The children lay there in the highest degree and deadly fever, unassisted, on bare ground, in sludge, mud, water. I will never forget those little creatures, those suffering for sins not committed. ${ }^{51}$

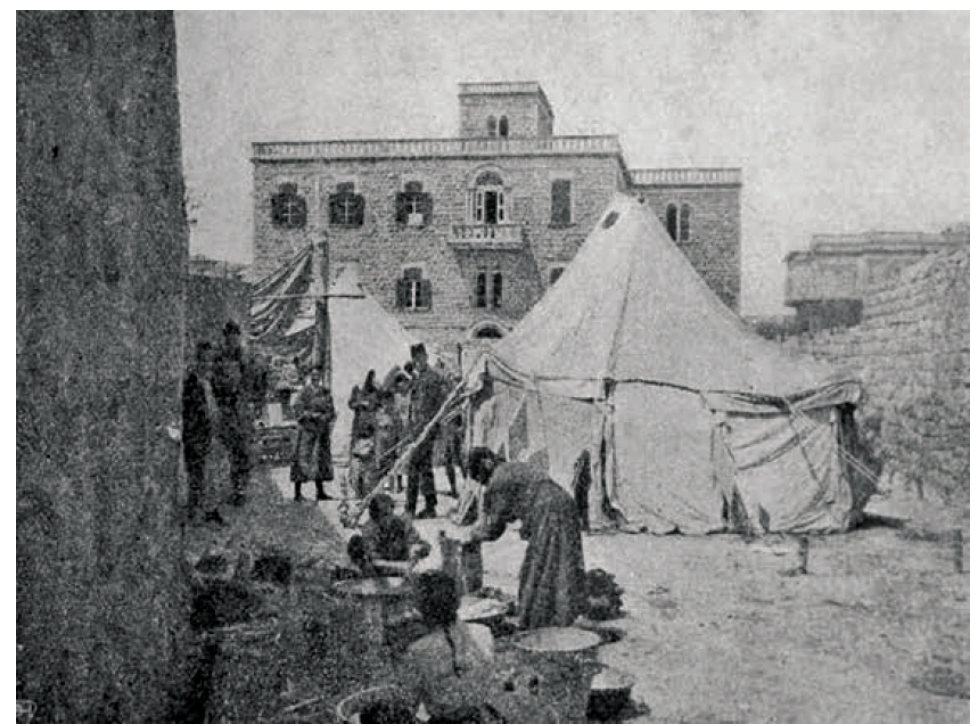

Figure 8. The life of remnants of the Christian population from Asia Minor; tents of refugees in Aleppo.

Source: Hansa, Hrůzy východu

Hansa was inspired by the work of various humanitarian workers he met. In Aleppo, it was the Swiss physician Max Müller of the German Christian Relief Society in the Orient (Christlicher Hilfsbund im Orient), who mainly treated the eye diseases of the refugees. ${ }^{52}$ During his stay in Lebanon, Hansa was cared for by Krikor Khahigian, the administrator of the local NER house, who arranged visits to refugee camps as well as meetings with humanitarian workers and prominent members of the Armenian community. The visit to an orphanage in the settlement Zouk Michail led by the distinguished figure of the Scandinavian Women's Missionary Workers (Kvindelige Missions Arbejdere), namely Maria Jacobsen (1882-1960), had a great impact on Hansa. During a tour of the orphanage, Hansa played and talked with the children, then spoke at length with Jacobsen about her current work and also about her experiences from WWI. Hansa was absolutely enchanted by her story and the operation of the orphanage..$^{53}$

51 Ibid., 100, see also 95-118. Hansa, Z potulek Orientem, 208-220.

52 Hansa, Hrůzy východu, 102.

53 Ibid., 116-118. Karekin Dickran, "Maria Jacobsen and the Genocide in Armenia," The Danish Peace Acad- 


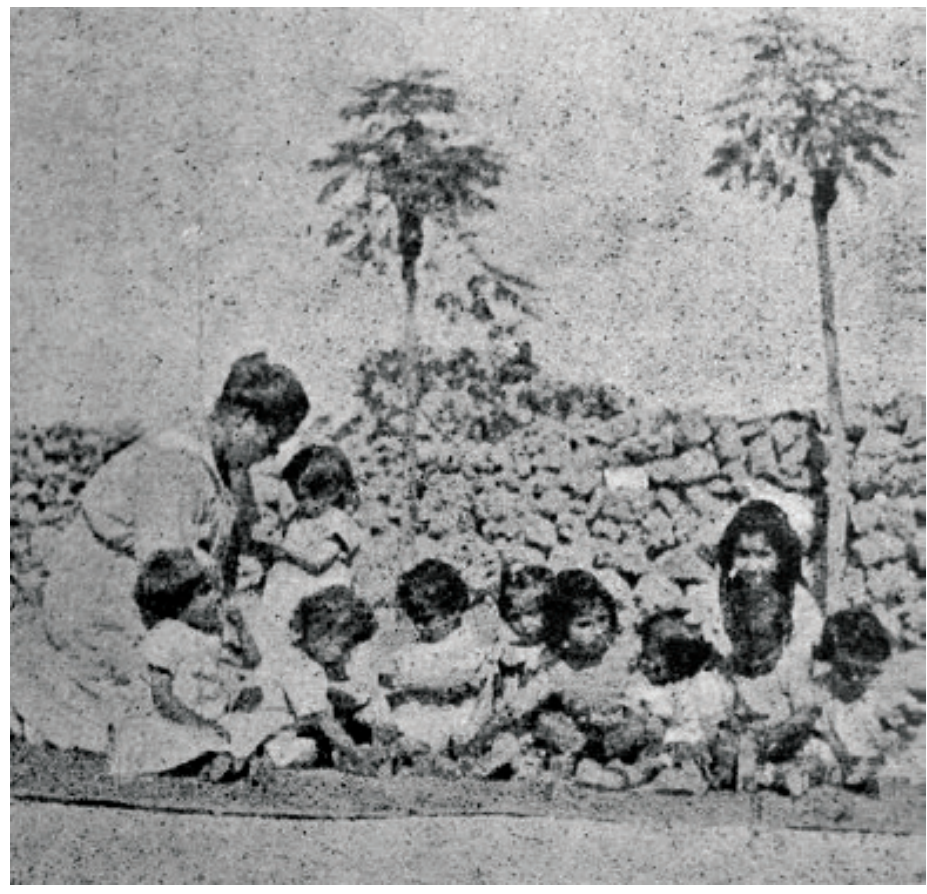

Figure 9. Madam M. Jacobsen with her sweethearts at the courtyard of the Danish orphanage at the Zuk Michael settlement in the Lebanon.

Source: Hansa, Hrůzy východu

Shortly before leaving Lebanon, Hansa met the Catholicos of Cilicia Sahak II (18491939), who appreciated his plan to organise aid for Armenian orphans in Czechoslovakia, but at the same urged caution and warned him against the opposition of various interest groups leaning towards support of Turkey in Europe. ${ }^{54}$

The most dramatic component of Hansa's activities was an eleven-day voyage on the Italian steamer Marate from Beirut to the Athenian port of Piraeus. The NER ship carried 896 Greek orphans, accompanied by Hansa and two American nurses. One of them, Silvia T. Eddy (1893-1954), is known by name..$^{55}$ During the voyage, the steamer got into a strong, fourteen-hour-long storm. The ship was crammed, poor hygiene prevailed, and some of the children were ill. Two boys even died during the trip, a four-year-old and the other an elev-

emy 2004, 1-3, at http://www.fredsakademiet.dk/library/karekin/ukmaria.pdf, accessed 01.09.2020; Inger M. Okkenhaug, "Scandinavian Missionaries, Gender and Armenian Refugees during World War I. Crisis and Reshaping of Vocation," Social Sciences and Missions 23, no. 1 (2010): 64-71; Revised and expanded translation of Chapter 8: "Maria Jacobsen, KMA og Fuglereden i Libanon" - "Maria Jacobsen, KMA, and the Birds Nest in Lebanon" from Matthias Bjørnlund, På herrens mark: Nødhjoelp, mission og kvindekamp under det armenske folkedrab (Copenhagen: Kristeligt Dagblads Forlag, 2015), at https://www.academia.edu/42881210/ Birds_Nest_on_the_Danish_orphanage_for_Armenian_genocide_survivors_in_Lebanon, accessed 20.05.2020. For more on Hansa's meeting with Jacobsen see Jandák, Arménsḱk genocidā, 509-511; see also 368-508.

54 Hansa, Z potulek Orientem, 212-213.

55 Amerikan Bord Heyeti (American Board), Istanbul, "Personnel records for Sylvia T. Eddy," American Research Institute in Turkey, Istanbul Centre Library, online in Digital Library for International Research Archive, item \#12102, at http://www.dlir.org/archive/items/show/12102, accessed 24.09. 2020. 
en-year-old. Despite all the difficulties, Hansa and the American nurses managed to keep the situation under control and avoided the threat of a fortnight's quarantine in the port of Athens. ${ }^{56}$

After a short visit to Athens and Thessaloniki, Hansa travelled by train to Prague in December 1922, where he wanted to begin his humanitarian work. ${ }^{57}$

\section{Writing, Lecturing and Organising in Czechoslovakia}

The first obstacle faced by Karel Hansa at the beginning of his humanitarian endeavours was the insufficient awareness on the part of the Czechoslovak public of the deportations and massacres of Armenian citizens during WWI. Unlike the states of the Entente, where the story of the Genocide of the Armenian nation was an indisputable part of the war experience, mediated by the daily press and amplified by the long-term missionary relationship in the region and the interests of war propaganda, ${ }^{58}$ the Habsburg Empire manifested the opposite dynamics. Germany and her ally, the Austria-Hungary, strictly censored their press during the war and prevented publication of reports about the genocide perpetrated by their ally. ${ }^{59}$ For instance, in the time of Hamidian massacres (1894-1896) the main Czech newspapers Narodni listy and Narodni politika published numerous and often detailed reports about this event almost on a daily basis, whereas during WWI only concise reports, denying or downplaying the violence against Armenians in the Ottoman Empire were published. After the end of the war, a small number of factually largely accurate reports about the Genocide were published in the Czechoslovak press, but they remained without much attention in the turbulent post-war period, and the Czechoslovak public as a whole remained poorly informed about the Genocide. ${ }^{60}$ Karel Hansa thus had to inform the Czechoslovak public before he could have started to organise humanitarian help and the collection of donations.

Karel Hansa started to lecture and to collect money for Armenian orphans in Prague and in other cities in Czechoslovakia, predominantly in southern Bohemia. He partially followed the tradition of traveller's lectures well established in the Czech speaking lands from the late 19th century. ${ }^{61}$ His lectures were organised by a wide range of organisations including various civic societies, schools, churches or even the army. Hansa's first known lecture after his return to Czechoslovakia was called "On the current fate of the remnants of the Armenian nation," and it was organised by the Czech Women's Club in Prague and held on 24 January $1923 .{ }^{62}$

56 Hansa, Hrưzy východu, 119-144.

57 Hansa, Z potulek Orientem, 256-267.

58 Jo Laycock, Imagining Armenia: Orientalism, Ambiguity and Intervention (Manchester: Manchester University Press, 2009), 99-143; Peter Balakian, The Burning Tigris: The Armenian Genocide and America's Response (New York: Perennial, 2004), 219-296.

59 Artem Ohanjanian, Armenia 1915: Austro-Hungarian Diplomatic Reports Prove the Genocide (Vienna: Society for Promotion of Armenian History and Culture, 2011), 227-241; Hilmar Kaiser, Imperialism, Racism, and Development Theories: The Construction of a Dominant Paradigm on Ottoman Armenians (Ann Arbor: Gomidas Institute, 1998), 21-32.

60 Jandák, Arménská genocida, 120-129, 215-218, 252-257, 354-356. Řoutil et al., Katastrofa křest’anů, 463475 .

61 Borovička, Velké dějiny zemi Koruny české: Cestovatelství, 536-539.

62 Národní politika, 24 January 1923, 4. 
In several extant reviews on Hansa's lectures from independent sources we can read that they "made a lasting impression" or that "[he] touchingly described the fate of the Armenian nation and its poor children; that his words moved hearts is evidenced also by the collected amount of money (90.5 crowns)". Every lecture was followed by a fundraising campaign for the Armenian orphans; recorded proceeds were around one hundred to a few hundred Czechoslovak crowns. The occasional problems recorded in the historical sources were related to low attendance. ${ }^{63}$ An entry in a local chronicle about a lecture for a child audience shows Hansa's good relationship with children and his ability to communicate with them: "The speaker with his almost childlike rendition made the lecture so pleasant that he held the attention of the children for almost two hours." ${ }^{94}$ Hansa himself collected a series of positive reviews of his lectures for the purpose of advertisement and communication with the authorities. ${ }^{65}$

The lectures were accompanied by approximately 180 images projected with a laterna magica. In July 1924, Hansa bought a small Praga Piccolo car to transport the projector and slides. He probably bought this car on credit, as was common at the time, and he sold it as soon as he temporarily stopped lecturing. ${ }^{66}$ The last known lecture at which he collected money for Armenian orphans took place in the town Netolice, on 14 April 1926 in south Bohemia. ${ }^{67}$ In the following two years, his lecturing activity stops and resumes in 1929, in connection with the forthcoming book of travels to Yugoslavia. ${ }^{68}$

Another component of Hansa's effort to overcome the lack of knowledge about the Armenian question in Czechoslovakia and to put his humanitarian activities on a firmer ground was the above-mentioned book Horrors of the East. This book can be seen as the first work in the Czech language systematically to map the nature of modern genocide and its consequences - phenomena which came to Central Europe 20 years later with the Nazi occupation. According to the holistic theory of genocide by the British historian Mark Levine, genocides local to the area were not an anomaly, for Eastern Europe and the adjacent areas including Anatolia (Leven calls them "The European Rimlands"), but a systemic trait of world historical development towards "a single, global, political economy composed of nation states." ${ }^{69}$

Hansa repeatedly amplified the historical importance and unprecedented nature of the violence in the Ottoman Empire at the beginning of the 20th century: "The credible eyewitness accounts of these acts prove that the atrocities committed against the Armenians

63 Hlas lidu, 24 December 1923, 3. Jihočeské listy, 28 April 1926, 3.

64 The lecture took place on 17 February 1926. SOkA ČB, collection Základní škola Ledenice, book 1, p. 29. 65 Police Directorate, advertisement for Hansa's lectures, c. 1930; reviews and recommendations of his lectures, 8 November 1946. Manuscript (1949-1950), 360-382.

66 Police Directorate, Hansa received his driver's licence on 1 February 1924. He bought a car on 21 July 1924, and sold it on 13 August 1926.

67 Jihočeské listy, 28 April 1926, 3.

68 Police Directorate, Hansa reported in a letter to the directorate his intention to give new lectures on the topic of Yugoslavia, 2 November 1929.

69 Mark Levene, The Crisis of Genocide, vol. I (Oxford: Oxford University Press, 2016), xiii. Beside Levene's two volume work, which directly examines the European Rimlands between 1912 and 1953, see also his overview on continuities and discontinuities: Genocide in the Age of the Nation State: Volume I: The Meaning of Genocide (New York: I. B. Tauris, 2008), 144-206. 
are unparalleled in human history." 70 However, he did not interpret this violence as part of modern historical processes, but, in agreement with historical orientalist views, saw it as a decline into "barbarism." "Hansa implicitly ascribed to the "civilised West" a paternalistic role in the enforcement of humanitarian principles on a global scale. In relation to the Armenian tragedy, the West in Hansa's interpretation ceased to be the personification of the positive values of progress and civilisation; on the contrary, the West betrayed these abstract values with its indifference towards the suffering Armenians. ${ }^{72} \mathrm{He}$ saw the survivors of the genocides as "victims of the reign of Young Turks, and the intrigues and weakness of European diplomacy." "73

The book Horrors of the East, which Hansa managed to write and publish in less than a year after his return to Czechoslovakia ${ }^{74}$ differs from Hansa's later works, which are mostly travelogues. As we have already mentioned above, Horrors of the East contains Hansa's testimony from Syria and Lebanon from 1922, which predominantly has the character of a travelogue; nonetheless, the first two parts of the book try systematically to depict Armenian history before the genocide and the genocide itself. Hansa did not have a university education, only short experience as editor of a forestry magazine. Despite the shortcomings, especially in grammar and in his dealing with the early Armenian history, Hansa managed, thanks to his determination, to compose a compilation of documents, commentaries and authentic experiences that persuasively outlined the main characteristics of the Armenian Genocide for the Czechoslovak public. In the descriptions of the violence itself, Hansa relied on primarily Western observers. ${ }^{75}$ The sources included in the book, though not systematically catalogued, contained much detail which must have had a lasting emotional impact on the readers.

To fulfil its goal of informing readers and encouraging their active contribution to the construction of a Czechoslovak orphanage in Lebanon, the publication of Horrors of the East needed to speak to the reader within a familiar ideological framework, which would have helped to legitimise such humanitarian action. Whereas the humanitarian reports of the League of Nations trove for political neutrality and humanitarian workers from United States of America presented their work in the framework of American exceptionalism, ${ }^{76}$ in the Czechoslovak milieu Hansa spoke to readers in the language of solidarity towards nations striving for self-determination. Horrors of the East was composed as tragic story of Armenian national history, which, due to violent crimes failed to achieve victory in "heroic

70 Hansa, Hrùzy východu, 89, see also 44, 91.

71 For more on the dichotomy of "civilization" and "barbarism" in genocide studies, see: Alexander L. Hinton, Thomas La Pointe, Douglas Irvin-Erickson (eds.) Hidden Genocides: Power, Knowledge, Memory (Newark: Rutgers University Press, 2014), 2-11.

72 Hansa, Hrůzy východu, foreword lacking pagination by Hakob Asatryan (2006, reprint). Hansa, Z potulek Orientem, 212.

73 Hansa, Hrìzy východu, 91.

74 The first known advertisement for the new book in Národni listy, on 23 November 1923, 10. The book is also briefly mentioned earlier in Světozor, 11 October 1923, 33.

75 Hansa quotes, for example, the German vice-consul Kuckhoff from Samsun, the American consuls Oscar H. Heizer from Trabzon, and Leslie A. Davis from Kharberd, and a number of unnamed sources. For examples of nurses of German Red Cross, American missionaries or German employees of the Bagdad Railroad, see Hrüzy východu, 49-80.

76 Watenpaugh, Bread from Stones, 57-123. 
fight of small nations for national and political liberation from the yoke of subjection." Hansa contrasted the Armenian tragedy with the situation of the "happily liberated Czechoslovak nation," which attained self-determination under favourable circumstances after the fall of the Austro-Hungarian Empire. At the same time, Hansa pondered on possible political solutions, and emphasised that Armenians as a nation wanted, and needed, a "motherland, their home." $" 77$

Hansa's appeal also aimed to direct the assistance towards the most vulnerable and evidently "innocent" group among the survivors - orphans. ${ }^{78}$ Solidarity with Armenians as a Christian nation played a secondary but indisputable role in the mobilisation of help. ${ }^{79}$

Humanitarian help in general played an important role in the Austro-Hungarian Empire at the end of WWI, when the food supply system collapsed, and food riots erupted on the streets of the monarchy. ${ }^{80}$ The "Czech Heart" organisation in particular contributed not only to an improvement in the supply situation of ethnically Czech citizens in the cities, but also to the takeover of control over supplies by the Czech national movement at the time of disintegration of the Habsburg Empire and creation of the new Czechoslovak state in the autumn of $1918 .^{81}$ In February 1919 the Czechoslovak Red Cross (CSRC) was founded with President Tomáš Garrigue Masaryk’s daughter, Dr Alice Masaryková (1879-1966) as its chairwoman. CSRC replaced the former Czech and Slovak units of the Austrian and Hungarian Red Cross (these were two separate organisations, Austrian and Hungarian respectively) and soon became a mass organisation with hundreds of thousands of members. CSRC engaged in the spheres of public health, youth education, social and humanitarian work and the preparation of health workers in case of war.

In 1919 CSRC received considerable support - exceeding 100 million Czechoslovak crowns - for post-war renewal from foreign donors, the vast majority of whom were from the United States. Likewise, foreign humanitarian workers were sent to Czechoslovakia. Czechoslovakia not only had experience with the international humanitarian movement from the position of recipient, but in 1921 CSRC in collaboration with the Czechoslovak Ministry for Foreign Affairs organised aid for those afflicted by the famine in Russia. Local CSRC organizations initiated a nationwide collection, and provided financial and material aid worth 3 million Czechoslovak crowns in total. In the 1920s the CSRC and the Czech government supported numerous Russian emigrants in Czechoslovakia, including scholarships for several thousands of Ukrainian and Russian students. A further example is the active resettlement of 5,000 Russian immigrants from Constantinople to Czechoslovakia at the turn of 1921-1922. ${ }^{82}$

77 Hansa, Hrůzy východu, 96.

78 Ibid., introduction lacking pagination and also closing appeal to reader for help, likewise without pagination. See also Hansa, Z potulek Orientem, 189, 289-290.

79 Hansa, Hrůzy východu, 97.

80 Rudolf Kučera, Rationed Life: Science, Everyday Life, and Working Class Politics in the Bohemian Lands, 1914-1918 (Oxford and New York: Berghahn, 2016); Ota Konrád, Rudolf Kučera, Cesty z apokalypsy (Prague: Academia, 2018).

81 Renata Tyršová (ed.), Pět let Českého srdce 1917-1922 (Prague: České srdce, 1922).

82 Radovan Lovčí, Alice Masaryková (Prague: Karlova Univerzita, 2007), 245-304; Otakar Dorazil, Čs. červený křiž 1919-1929 (Prague: Československý Červený kříž, 1929); NA, collection Ministerstvo zahraničních věcí Ruská pomocná akce, inv. no. 19, 20, 53, 70, 71, 107. 
Hansa felt it crucial to build on the existing Czechoslovak infrastructure of humanitarian help. He had already received a promise of support from unnamed Czechoslovak officials during his stay in Syria. ${ }^{83}$

After his return to the homeland he met with the chairwoman of the CSRC, Dr. Alice Masarykova, on 9 March 1923 and asked her to donate medicine and other necessities for refugees in Syria and Lebanon. He was allegedly promised "a large consignment," the archive of CSRC was lost during WWII and no further information on the matter can be found in Hansa's writings. However, the establishment of the so-called "Hansa's fund for Armenian orphans" at the CSRC is well documented. The greater part of the money was collected through public lectures. In addition, Hansa also asked for contributions in his books and promised to donate a small part of the sales income to the fund. For greater transparency, the money was sent directly by the organisers of the lectures and not by Hansa himself. ${ }^{85}$ Hansa's fund at CSRC raised approximately 5,000 Czechoslovak crowns (the equivalent to 150 U.S. dollars at that time), which roughly corresponded to the budget of one local organisation of the CSRC, a modest annual scholarship for one Armenian student or the amount required to provide for several orphans in Lebanon for a year. ${ }^{86}$

The next important figure to whom Hansa reached out was Dr Václav Girsa (18751954). Their meeting took place on 27 March 1923 at the Czechoslovak Ministry for Foreign Affairs. Girsa was one of the highest-ranking officials of the Ministry, and former head of the commission to support those afflicted by famine in Russia in the years 1921-1922. Thanks to Hansa's mediation the ministry, much as in case of Russian and Ukrainian students, allowed 50 Armenian students to study at Czechoslovak universities and supported them with scholarships. Already in 1923 the first students applied, and in the next year the Armenian student association in Czechoslovakia was founded ${ }^{87}$ This was clearly one of Hansa's biggest achievements. The former Armenian Prime Minister Alexander Khatisian (1874-1945) attended Hansa's lecture during his stay in Prague on December 1923 and accompanied him to express his thanks to the Czechoslovak government for their support of Armenian students. ${ }^{88}$

At the international level, Hansa cooperated with the Armenian Catholic Congregation

83 Hansa, Z potulek Orientem, 208-209.

84 Letter to Mekhitarists, April 15, 1-2. In his correspondence with the Mekhitarist Congragation in Vienna Hansa details his activities. We have in our possession digital copies of three German letters by Hansa dated April 15, May 27 and August 23, 1923 that were kindly provided to us by Haig Utidjian. Henceforth this correspondence will be cited as "Letters to Mekhitarists." For more details on the letters see Utidjian, The Art of the Armenian Book, 210-213.

85 Ibid. Jihočeské listy, 28 April 1926, 3. Hansa, Hrůzy východu, 97, 155. Hansa, Z potulek Orientem, 289-290. Hansa pledged do give 1 Czechoslovak crown to the fund for every sold copy of his books (1923, 1925). The prices of his books were 20 and 35 crowns, respectively.

86 Výroční zpráva Čs. červeného křiže (Prague: Československý Červený křiž 1921-1925); NA, collection Ministerstvo zahraničních věcí - Ruská pomocná akce, inv. no. 70, 71. Hansa estimated that to support one orphan in Lebanon would cost 2-3 U.S. dollars monthly. Hansa, Hrůzy východu, 98.

87 Letters to Mekhitarists, April 15, May 27 and August 23, 1923. Jaroslav Vaculík, "Masarykův spolupracovník MUDr. Václav Girsa," in T. G. Masaryk, jeho spolupracovníci a vznik československého státu (Hodonín: Masarykovo muzeum, 2009), 102-106; AHMP, collection Spolkový katastr, sign. X/0317, Arménský studentský svaz v ČSR (1924-1936).

88 Lidové listy, 11 December 1923. Manuscript (1949-1950), appendix “Poznávejte svět!," 3-4. 
of Mekhitarists in Vienna. The book Horrors of the East dedicates considerable space to the history of the Congregation, and Hansa's correspondence with the Mekhitarists shows that some of the photographs and illustrations in the books are from the Congregation. ${ }^{89}$ Hansa also participated in the conference of the International Near East Association in Geneva at which he presented his photographs from Lebanon and Syria. ${ }^{90}$

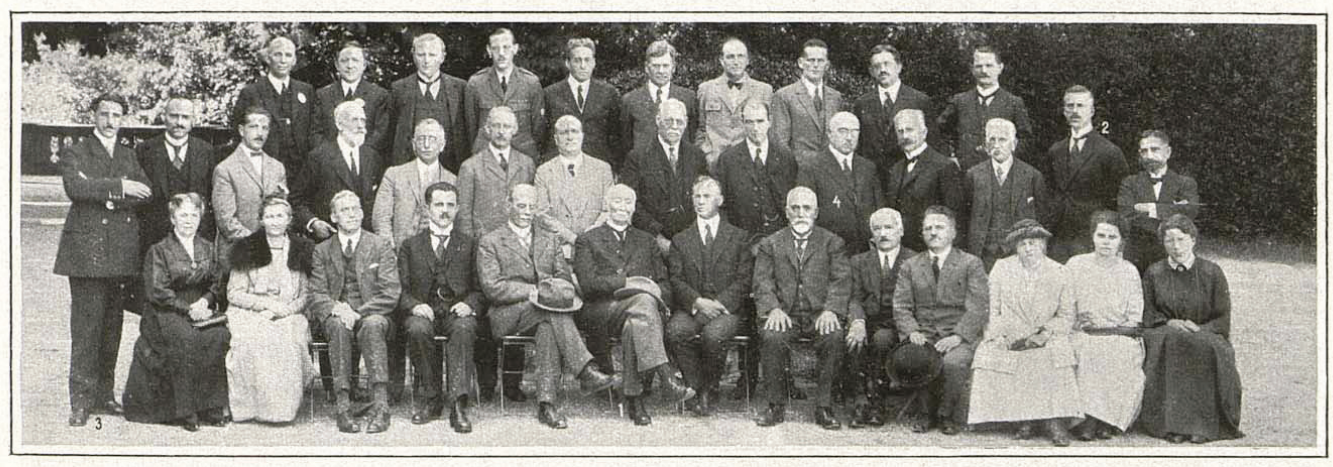

ÚČASTNÍCI KONGRESU ,MEZINÁRODNÍ SPOLEČNOSTI PRO BLIZKÝ VÝCHOD“

konaného dne 7.-15. zář́i 1923 v Ženevě za předsed. pres. Aug. de Morsier (1), gen. sekr. Gordona L. Berryho (2) a delegátủ z celého světa. 3. Čsl. del. K. Hansa, orient. cestovatel a autor spisu ,Hrủzy Východu“. 4. Dr. Alexandr Khatissian, pres. armén. republiky.

Figure 10. Participants of the congress of the International Near East Association held 5-15 September 1923 in Geneva, chaired by President Auguste de Morsier [1864-1923] (1), General Secretary Gordon L. Berry [1884-1932] (2), and attended by delegates from around the world. The Czechoslovak delegate Karel Hansa, orientalist traveller and author of Horrors of the East (3). The President of the Armenian Republic Dr Alexandr Khatissian [sic. Former Prime Minister, April 1919 - May 1920] (4).

Source: Světozor, October 11, 1923, 33

The question of cooperation with various organizations and individuals, which key to the success of his activities, because the money he had collected could not be enough to build an orphanage, revealed the limits of Hansa's abilities as a humanitarian worker.

In the autumn of 1924, Hansa established contact with Armenag S. Baronigian (1890?), director of the Armenian Committee for Medical Aid and Evangelization (Armenische Hilfskomitee zur Unterstützung ärztlicher Mission und Evangelisation). Baronigian offered Hansa a position in his organisation, and suggested that Hansa send him money from his own fund to Baronigian's organisation in Germany. To this end, he visited Hansa in Prague and invited him to Nuremberg. During the visit to Prague, however, there was a dispute between the two men. In his correspondence, Baronigian portrays Hansa as a man who constantly complains about his misery and the lack of support for his fund from prominent Armenians, but who acts non-transparently, spends time in pubs and is unreliable in financial matters. Baronigian even went so far as to ask Hansa openly if his activities were fraudulent. According to the German historian Uwe Feigel, Baronigian was involved in court proceed-

89 Hansa, Hrůzy východu, 14-20. Letters to Mekhitarists, April 15, May 27 and August 23, 1923. 90 Manuscript (1949-1950), appendix "Poznávejte svět!," 3. Hansa, Hrůzy východu, 147-149. Letter to Mekhitarists, 23 August 1923. Jihočeské listy, 28 April 1926, 3. 
ings in Germany for embezzling money in a charity, but was eventually acquitted by the Imperial Court. ${ }^{91}$ This experience could have also helped shape Baronigian's critical view of Hansa. As we know from the statement of the CSRC accountant Josef Kapr, Hansa's fund was not a fraud, ${ }^{92}$ but Hansa's unbalanced nature and the resulting difficulties in cooperating with other people were real.

From 1923, Hansa tried to establish a Czech association in support of deprived Armenian orphans, but due to a lack of interest its inaugural meeting did not occur until October 8, 1924. After a few weeks, however, a trivial dispute escalated between Hansa - who was both the association's chairman and its secretary - and Karel Tunkl, who served as its vice-chairman. According to Tunkl, Hansa acted in too "lordly" a manner" when writing letters to Germany and Geneva. For example, in a draft letter to Geneva Hansa spoke of "his association," "his committee," instead of writing "our association," "our committee," as Tunkl would have preferred. ${ }^{94}$ Hansa allegedly replied that he would not be lectured to, because the association only existed for 10 days and he had been working for Armenian orphans for two years. Hansa, who himself admits in his later lawsuit that he was "rather nervous" as a result of his military service and his stay in the Near East, ${ }^{95}$ after another exchange of views tore up the letter and left the meeting. At further meetings of the association the dispute grew into a bitter struggle for control of the association. ${ }^{96}$ Tunkl and his wife and friends, whom he brought to the association when it was founded, effectively controlled it, deprived Hansa of the offices he held and of his membership, and took further steps, including an unsuccessful attempt to take over Hansa's fund at the CSRC. ${ }^{97}$

Hansa decided in December 1924 to sue Tunkl et al. for defamation, at the Smíchov District Court. The dispute dragged on for almost a year and ended with an out-of-court settlement on 25 November 1925, in which the defendants stated that they had not made their statements about Hansa with malicious intent and "could not blame him for anything dishonest." The Czech traveller withdrew his lawsuit and both parties paid for their court costs themselves. ${ }^{98}$ Records of the association's day-to-day activities with the new leadership without Hansa stopped in $1925 .{ }^{99}$ Hansa's inability to lead the association by consensus with other members, along with Tunkl's reckless ambitions and determination to remove Hansa from the association's collective, led to the embarrassing failure of the association.

91 Uwe Feigel, Das evangelische Deutschland und Armenien (Göttingen: Vandenhoeck und Ruprecht, 1989), 288.

92 AHMP, collection Okresní civilní soud po Prahu-sever [Regional Court for Prague North], zn. 96, sign. T VI 1906/24, p. 45. Witness testimony of the accountant of CSRC Josefa Kapr, 24 November 1925.

93 Ibid., Hansa's complaint, 16 December 1924. The word "pánovitě” (“in a lordly manner”) Hansa himself repeated in describing the incident in his complaint.

94 Ibid., 28, statement by the defendants, 28 January 1925.

95 Ibid., 2, Hansa's complaint, 16 December 1924.

96 Ibid., 27-29, statement by the defendants, 28 January 1925.

97 Ibid., 45, testimony by Kapr.

98 Ibid., 47.

99 AHMP, collection Spolkový katastr, box 78, sign. II/0635, Český spolek pro podporu strádajících arménských sirotků. The association was formally dissolved after a prolonged period of inaction, on 1 January 1928. 


\section{Later years}

Hansa's activity in connection with the Armenian question, as we know, ended in the year 1926. In later years, Hansa used his experience as a traveller and writer, lecturing and writing about his travels to the allied countries of interwar Czechoslovakia and the easternmost part of Czechoslovakia itself.

In May 1927 he went to France, where he travelled around Brittany, studied the language and worked. ${ }^{100}$ In the summer of 1929, Hansa and his girlfriend travelled to Yugoslavia, a country that was a close ally of Czechoslovakia in the Little Entente and a popular tourist destination. ${ }^{101}$

Another of Hansa's travel destinations was Carpathian Ruthenia. This undeveloped "wild east" of Czechoslovakia, with which Prague in many respects had a repressive relationship shaped by the idea of a civilizational mission of the Republic, was an object of interest not only for Czech officials, police officers, soldiers, teachers, tourists, writers and adventurers, but also for social and humanitarian workers. ${ }^{102}$ Hansa appears here not only as a traveller and writer, but also again as a philanthropist. In his first book on Carpathian Ruthenia he focused on the local history of the area, ${ }^{103}$ and in his second he depicted distributing gifts to poor children there, which he organised for Orthodox Christmas Day in January 1937. Young schoolchildren were gifted 500 packages. The most valuable gifts consisted of 71 pairs of shoes, purchased with the permission of the CSRC for 2,000 crowns, originally raised for Armenian orphans through Hansa's fund, which in the meantime had grown. ${ }^{104}$

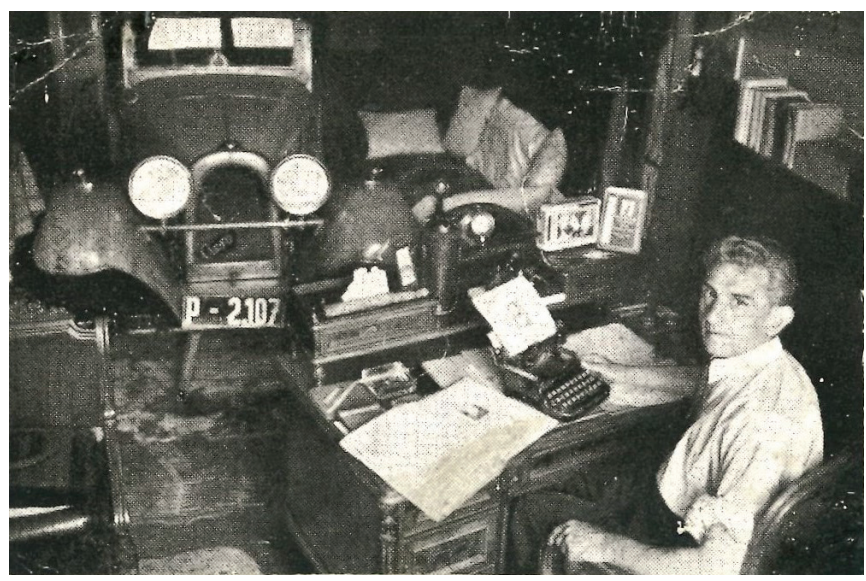

Figure 11. Extraordinary photograph of Hansa portraying his dual aspects as writer and motorist that characterise his more rounded identity as a travel writer. A caption reads: "The 'Aero' vehicle - an ever reliable friend, which in the evening May 20, 1941 came to an 'unusual' garage, namely my living room!"

\section{Source: Family collection}

100 Manuscript (1949-1950), 314-318.

101 Hansa, Léto pod jihoslovanským nebem (Prague: self-published, 1930), 324.

102 Konrád et al., Cesty z apokalypsy, 278-296. Dorazil, Čs. červený křiž 1919-1929, 128-142.

103 Hansa, Stero črt a obrázků z Podkarpatské Rusi (Prague: self-published, 1935), 530. The Slovak historian Michal Falat is currently conducting research on Hansa's texts about Carpathian Ruthenia.

104 Hansa, Podkarpatoruská vánoční idyla (Prague: self-published, 1937), 9-13, 43-44, 79-81, 97-108. 
In 1925 Hansa outlined the possibility of handing over the fund to the International Near East Association, ${ }^{105}$ but at least a substantial portion of the money was never used to help Armenian orphans, which may be attributed to Hansa's mismanagement of the fund. The rest of the money in the fund for the victims of the Armenian Genocide ended up in the hands of the Nazis, as a result of the occupation of Czechoslovakia by the German army in 1939. The Nazis abolished the CSRC, confiscated its property and persecuted many of its employees. ${ }^{106}$

The Nazi occupation prevented Hansa from travelling and lecturing. After the end of the war, Hansa set out in a two-seater open aero car made in $1931{ }^{107}$ with his travel lectures to various halls in Czechoslovakia. The ageing car and its driver were reminiscent of the period of the first Czechoslovak Republic and increasingly were out of place in the new post-war period. After the establishment of the communist dictatorship in February 1948, his lecturing activities gradually died down, and although he never stopped writing, none of his books were published. In the last years of his life he lived alone, in relative poverty, in the Smíchov, one of Prague's working class districts. Karel Hansa died on 4 June 1967 at the age of $76 .{ }^{108}$ His apartment was subsequently robbed, before the arrival of his relatives. Hansa's papers, including the manuscript of his book For Peace with Word and Image, were lost. ${ }^{109}$

\section{Conclusion}

Hansa's life was filled with contradictions, in numerous ways. His childhood was unstable, but he retained ties to his family, especially to his mother. Hansa was a mediocre pupil who became a writer as an adult. He understood children well and knew how to approach them in their world; at the same time, he never married and remained childless. He had ambitions to become a prominent humanitarian, but as he himself noted in 1937, his activities were limited by his humble background: "The poor mortal didn't have enough money to act with dignity in the role of the heavenly benefactor." ${ }^{110}$ Hansa's qualities included purposefulness, diligence and ambition. At the same time, however, he was an unstable personality. On the one hand he was perceptive and sensitive, and on the other he was attention-seeking and petulant. His personality was also shaped by the trauma stemming from his war experiences, which had resulted in his serious disability. Despite all the contradictions, wandering from place to place and writing remained the constant in his life.

His book Horrors of the East became the first work in the Czech language systematically to address the Armenian Genocide and thus the hitherto unnamed phenomenon of modern genocide in general. In particular, Hansa's accounts of the lives of Armenian Genocide survivors and the activities of the humanitarian workers he met in Syria and Lebanon in 1922

105 Police Directorate, Hansa's letter to the directorate, 19 January 1925, 2.

106 Manuscript (1949-1950), 334.

107 Police Directorate, application to the motor vehicle registry, 11 July 1946.

108 Cukr, "K dobrodružnému životu Karla Hansy,” 60-61.

109 Interview with Jarmila Jedlinská, niece of Karel Hansa, conducted by the authors on 26 May 2019 in České Budějovice. Manuscript (1949-1950), appendix "Poznávejte svět!," 10.

110 Hansa, Podkarpatoruská vánoční idyla, 12. 
are of significant historical value. Hansa brought about the extension of the scholarship program of the Czechoslovak Ministry of Foreign Affairs originally intended for Russian and Ukrainian emigrants to include 50 Armenian students. However, his attempt to establish a Czechoslovak association in support of deprived Armenian orphans ended in failure, mainly due to personal disputes. Hansa's three-year public lecturing activities together with his fundraising efforts were, sadly, far from successful in raising sufficient funds to establish a Czechoslovak orphanage in Lebanon, as Hansa's was in essence an isolated individual endeavour. Hansa's activities were further complicated by the fact that the Czechoslovak public was very poorly informed about the Armenian Genocide during WWI, due to censorship in Austria-Hungary. In addition, Czechoslovakia lacked any previous connection to the event through missionaries and diplomats, which was crucially important to humanitarian initiatives in the United States and various European countries.

Modern humanitarianism originated in the West in the shadow of the politics of the Great Powers, of nationalism and of colonialism as a "weak force"111 in the international arena. Hansa's relationship with modern humanitarianism was formed through his contact with humanitarian workers and their institutions, as well as with Armenian Genocide survivors. Hansa attempted to mediate his experience with these two groups in Czechoslovakia. He presented humanitarian workers as a role model from foreign countries that were more developed than semi-peripheral Czechoslovakia. In line with the ideology of nationalism, then prevailing in Czechoslovakia, he depicted survivors as objects of solidarity between small nations striving for self-determination. Hansa's biography broadens our understanding of how the "weak force" of humanitarianism as a reaction to the catastrophe of the Armenian Genocide spread on a global scale, and at the same time acquired new meanings and reached its limits.

\section{Acknowledgement}

Our thanks belong to our colleagues and friends Andran Abramjan, Tigran Abramjan, Hakob Asatryan, Ema Kovalčíková, Jan Štemberk and Anna Sochová who kindly helped us with our research in numerous ways. We would like to thank Hansa's relatives Jaroslava Vlachová and Jarmila Jedlinská. We are especially grateful for the friendly guidance and selfless help of Haig Utidjian.

111 Chris Gratien (host), Keith D. Watenpaugh, "The Middle East in the Making of Modern Humanitarianism," Ottoman History Podcast, no. 238, 8 April 2016, 8:00-9:00. See also Watenpaugh, Bread from Stones, 4-29. Watenpaugh defined the term "weak force" in the podcast. He did not use it explicitly in his book on the subject, nevertheless, we find it useful here. 